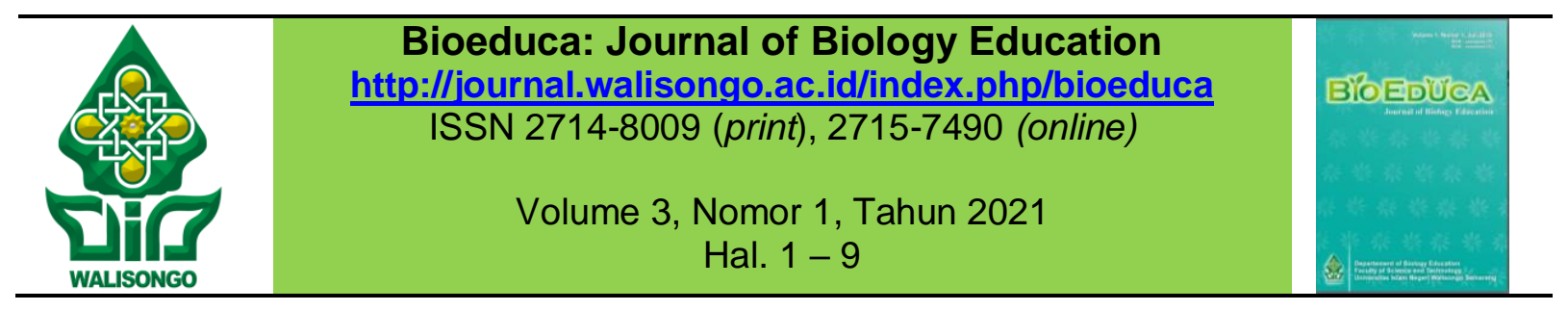

\title{
Implementasi Discovery Learning dalam Pembelajaran Biologi Materi Struktur dan Fungsi Jaringan Hewan
}

\author{
Manganju Manik ${ }^{1 *}$, Fauziyah Harahap ${ }^{2}$ \\ ${ }^{1,2}$ Pendidikan Biologi, Universitas Negeri Medan \\ *Email : manikjuju@gmail.com
}

\begin{tabular}{|c|c|}
\hline Informasi Artikel & ABSTRAK \\
\hline $\begin{array}{l}\text { Submit: } 03-10-2020 \\
\text { Diterima: } 31-03-2021 \\
\text { Dipublikasikan: } 31-03-2021\end{array}$ & $\begin{array}{l}\text { Penelitian Tindakan Kelas (PTK) ini dilakukan untuk } \\
\text { mendapatkan hasil dari Implementasi Discovery Learning } \\
\text { terhadap hasil belajar siswa pada materi struktur dan fungsi } \\
\text { jaringan hewan di SMA Negeri } 3 \text { Medan. Sistem implementasi ini } \\
\text { dilakukan dalam dua siklus, masing - masing siklus terdiri dari } \\
\text { empat tahapan yaitu: perencanaan, tindakan, pengamatan } \\
\text { (observation) dan refleksi. Terdapat } 13 \text { Kelas XI MIA sebagai } \\
\text { populasi penelitian, di mana siswa kelas XI MIA-8 yang berjumlah } \\
42 \text { orang terdiri dari } 20 \text { siswa laki-laki dan } 22 \text { siswa perempuan } \\
\text { sebagai subjek penelitian ini. Analisis data menggunakan teknik } \\
\text { deskriptif kuantitatif. Peningkatan hasil belajar siswa mengalami } \\
\text { perubahan yakni } 85,71 \% \text { pada siklus ke I dan } 97,62 \% \text { pada siklus } \\
\text { ke II. Kesimpulan dari hasil penelitian menunjukkan bahwa } \\
\text { adanya peningkatan hasil belajar siswa dan masuk ke dalam } \\
\text { kategori tinggi. } \\
\text { Kata kunci: discovery learning; hasil belajar; pembelajaran } \\
\text { biologi. }\end{array}$ \\
\hline Penerbit & ABSTRACT \\
\hline $\begin{array}{l}\text { Program Studi Pendidikan } \\
\text { Biologi, Fakultas Sains dan } \\
\text { Teknologi, UIN Walisongo } \\
\text { Semarang }\end{array}$ & $\begin{array}{l}\text { This Classroom Action Research (CAR) aims to determine the } \\
\text { effect of the implementation of Discovery Learning models } \\
\text { towards learning outcome of students on the Structure and } \\
\text { Function of Animal Tissue subject matter at SMA Negeri } 3 \\
\text { Medan. This study was conducted in two cycles, each cycle } \\
\text { consist of four phases: planning, action, observation and } \\
\text { reflection. The population were } 13 \text { classes of XI MIA, the subjects } \\
\text { were XI MIA-8 student, which is amounted to } 42 \text { people, } \\
\text { consisting of } 20 \text { male students and } 22 \text { female student. Data } \\
\text { analysis was performed with a descriptive quantitative technique. } \\
\text { Improving student learning outcomes has exceeded } 85.71 \% \text { in } \\
\text { the first cycle and } 97.62 \% \text { in the second cycle. The conclusion } \\
\text { from the research is an increase in students learning outcomes } \\
\text { and the results of student learning has high category. } \\
\text { Keywords: discovery learning; learning outcome; biology } \\
\text { learning. }\end{array}$ \\
\hline
\end{tabular}

Copyright (O2021, Bioeduca: Journal of Biology Education

\section{PENDAHULUAN}

Pembelajaran yang ideal ditandai dengan sifatnya yang menekankan pada pemberdayaan siswa secara aktif. Pembelajaran yang ideal adalah proses belajar mengajar yang bukan saja fokus kepada hasil yang dicapai peserta didik, namun 
bagaimana proses pembelajaran yang ideal mampu memberikan pemahaman yang baik, kecerdasan, ketekunan, kesempatan dan mutu serta dapat memberikan perubahan perilaku dan menerapkan dalam kehidupan mereka. Berdasarkan pengalaman penulis selama melakukan pembelajaran di SMA Negeri 3 Medan di kelas XI MIA-8 ditemukan beberapa fakta berikut: (1) Proses pembelajaran menggunakan media lebih menarik bagi siswa; (2) guru telah berupaya melibatkan siswa dalam pembelajaran, melalui tanya jawab, meminta siswa untuk menjelaskan materi yang telah di baca ke depan, dan lain-lain, namun umumnya siswa belum mau untuk terlibat aktif (3) siswa kurang memperhatikan guru saat menerangkan pelajaran (4) siswa belum mampu menguasai materi pembelajaran di mana siswa yang dapat mencapai KKM hanya sebanyak $50 \%$. Dalam kenyataan yang ada, proses pembelajaran yang ditemukan di lapangan tidak sesuai dengan kondisi ideal pembelajaran semestinya.

Berdasarkan fakta - fakta di atas, yang menjadi fenomena masalah adalah fakta yang berkaitan dengan hasil belajar sangat perlu mendapat perhatian untuk ditindaklanjuti. Jika keadaan ini tidak segera diperbaiki maka dikhawatirkan akan berdampak pada hasil belajar siswa yang rendah dan proses kenaikan kelas. Hasil belajar pada penelitian ini dibatasi pada hasil belajar kognitif. Sumaji (Patta Bundu 2006: 8) menyatakan bahwa "hasil langsung pendidikan untuk kriteria keberhasilan pendidikan terdiri dari aspek kognitif dan non kognitif". Dari ketiga ranah tersebut, ranah kognitif merupakan ranah yang paling mudah untuk mengukurnya yaitu dapat dilihat melalui hasil belajar berupa tes normatif dan sumatif.

Mencermati penyebab masalah sebagaimana telah dipaparkan di atas melalui tindakan ini akan dilakukan penelitian perbaikan pembelajaran untuk meningkatkan hasil belajar siswa di dalam kelas. Perbaikan belajar yang dilakukan dalam penelitian ini melalui penerapan model pembelajaran discovery learning. Model discovery learning mampu membantu meningkatkan keaktifan siswa dalam proses pembelajaran dengan siswa menemukan informasi sendiri sehingga menunjukkan peningkatan hasil belajar siswa baik di sekolah (Yuliana, N. 2018). Hasil penellitian Ilahi (2012) juga menunjukkan bahwa model discovery learning ini dalam prosesnya menggunakan kegiatan dan pengalaman langsung sehingga akan lebih menarik perhatian anak didik dan memungkinkan pembentukan konsep-konsep abstrak yang mempunyai makna, serta kegiatannya pun lebih realistis. Penjelasan lain juga menerangkan bahwa kegiatan penemuan yang dilakukan oleh manusia itu sendiri dan dilakukan secara aktif akan memberikan hasil yang paling baik, serta akan lebih bermakna bagi dirinya sendiri (Bruner dalam Sujana, 2014). Melalui model discovery learning siswa menjadi lebih dekat dengan apa yang menjadi sumber belajarnya, rasa percaya diri siswa akan meningkat karena dia merasa apa yang telah dipahaminya ditemukan oleh dirinya sendiri, kerja sama dengan temannya pun akan meningkat, serta tentunya menambah pengalaman siswa (Putrayasa, 2014).

Berdasarkan masalah mengenai proses belajar mengajar yang ada di sekolah yang telah dipaparkan di atas serta berdasarkan hasil penelitian terdahulu mengenai penerapan discovery learnig maka penulis akan melakukan penelitian mengenai implementasi model pembelajaran discovery learning dalam pembelajaran biologi. 


\section{METODE PENELITIAN}

Penelitian ini merupakan penelitian tindakan kelas (Classroom Action Research), penelitian ini memiliki tahap-tahap beberapa siklus. Prosedur penelitian tindakan untuk kelas ini terdiri dari 2 siklus. Tiap siklus dilaksanakan dalam objek penelitian dan siklus akan berhenti jika siswa telah mencapai ketuntasan belajar secara klasikal. Penelitian tindakan kelas ini dilaksanakan dengan menggunakan model Arikunto (2010) yang terdiri dari empat tahap yaitu: "Perencanaan, Pelaksanaan, Pengamatan dan Refleksi.

Penelitian dilaksanakan di SMA Negeri 3 Medan. Subjek penelitian adalah siswa kelas XI MIA-8 SMA Negeri 3 Medan, semester gasal Tahun Pembelajaran 2017/2018. Objek dalam penelitian ini adalah hasil belajar siswa yang digolongkan pada domain kognitif dalam pembelajaran biologi pada materi Struktur dan Fungsi Jaringan Hewan dengan menerapkan Model Discovery Learning.

Dalam penelitian ini diberikan tes setiap siklus berupa tes pilihan ganda berjumlah 10 soal yang diberikan sebelum dan sesudah pembelajaran. Soal tersebut telah divalidasi oleh guru pamong dan dosen pembimbing sebelum digunakan. Teknik analisis data yang digunakan berupa statistik deskriptif, yaitu mendeskripsikan, mencatat dan menganalisis data. Analisis data dilakukan untuk: mengetahui tingkat penguasaan siswa terhadap materi pelajaran yang diajarkan; mengetahui ketuntasan belajar secara perorangan (individual); dan mengetahui persentase siswa yang sudah tuntas belajar secara klasikal. Dalam penelitian Nasution, L.,M. (2017) untuk memudahkan pembaca dalam memahami hasil penelitian yang sudah dilaksanakan, hasil analisis data statistik deskriptif harus disajikan dalam bentuk tabel data dan grafik data yang berupa grafik batang atau balok.

\section{HASIL DAN PEMBAHASAN}

Pertemuan I pada siklus I ini dengan sub-materi pelajaran adalah jaringan hewan, tindakan yang dilakukan adalah penerapan model Discovery Learning dan dijabarkan hasil penelitiannya sebagai berikut: a. Perencanaan, hal-hal yang dilakukan pada tahap perencanaan siklus I adalah sebagai berikut: (1) Membuat RPP dengan kompetensi dasar "Menganalisis keterkaitan antara struktur sel pada jaringan hewan dengan fungsi organ pada hewan", (2) Menyiapkan sarana dan prasarana yang akan digunakan dalam proses pembelajaran berupa: Infocus Proyektor dan LKPD, (3) Menyusun dan menyiapkan lembar jurnal penilaian siswa, (4) Menyiapkan soal evaluasi siswa. b. Pelaksanaan Tindakan, Pada pertemuan pertama siklus I dilaksanakan, Peneliti memulai pembelajaran dengan mengucapkan salam dan mengecek kehadiran siswa. Setelah mengkondisikan kesiapan belajar siswa maka guru memberikan soal pretest untuk mengetahui tingkat kemampuan siswa mengenai sub-materi jaringan hewan sebelum diberikan perlakuan dengan melakukan model pembelajaran Discovery Learning. Setelah pretest selesai, guru memberikan apersepsi mengenai jaringan hewan kemudian menyampaikan tujuan pembelajaran yang akan dicapai, yaitu: melalui kegiatan pembelajaran dengan pendekatan saintifik menggunakan model pembelajaran discovery learning peserta didik dapat 
menganalisis keterkaitan antara struktur sel pada jaringan hewan. Pada kegiatan inti pembelajaran, guru menjelaskan kepada siswa tentang jenis - jenis jaringan hewan. Setelah itu peneliti membimbing siswa membentuk 10 kelompok belajar yang terdiri dari 4-5 orang lalu membagikan LKPD kepada siswa. Kemudian guru memberikan waktu kepada siswa untuk berdiskusi mengerjakan LKPD dengan mengacu pada studi literatur baik dari buku pelajaran maupun dari internet. Setelah siswa selesai mengerjakan LKPD, maka guru meminta setiap kelompok mempresentasikan hasil diskusinya dan kelompok yang lain menanggapi. Guru memberi koreksi apabila ada konsep yang salah dan meminta siswa untuk menggaris bawahi hal-hal yang penting pada buku atau mencatatnya di buku catatan. Guru mengakhiri pembelajaran bersama siswa dengan memberikan kesimpulan materi yang telah dipelajari.

Pertemuan II siklus I dilaksanakan dengan cara Guru memulai pembelajaran dengan mengucap salam dan mengecek kesiapan siswa belajar. Kemudian guru melakukan apersepsi dengan menanyakan pelajaran yang sudah lewat kemudian melanjutkan pelajaran dengan presentasi kelompok berikutnya. Setiap kelompok mempresentasikan hasil diskusinya dan kelompok yang lain menanggapi. Guru memberi koreksi apabila ada konsep yang salah dan meminta siswa untuk menggaris bawahi hal-hal yang penting pada buku atau mencatatnya di buku catatan. Guru mengakhiri pembelajaran dengan meminta perwakilan siswa untuk memberikan kesimpulan materi yang telah dipelajari. Guru memberikan soal post test sebanyak 10 butir soal pilihan berganda, selesai itu guru menyuruh siswa agar mempelajari materi untuk pertemuan selanjutnya.

Selanjutnya untuk c. Observasi dan evaluasi pada siklus I diperoleh hasil-hasil sebagai berikut: Hasil Belajar Siswa diketahui dengan cara guru melaksanakan kegiatan evaluasi dengan memberikan pretest (10 soal pilihan berganda) dan post test (10 soal pilihan berganda) dan memberikan waktu 10 menit kepada siswa untuk mengerjakannya pada setiap sesi evaluasi. Berdasarkan nilai rata-rata yang diperoleh siswa, diketahui bahwa nilai rata-rata hasil belajar siswa adalah 72,62 . Maka melalui persentase nilai dari masing-masing siswa dapat ditentukan tingkat penguasaan materi pelajaran dalam tes yang telah dilaksanakan. Pada pretest dan post test siklus I diperoleh persentase ketuntasan belajar siswa sebagaimana ditunjukkan pada gambar 1.

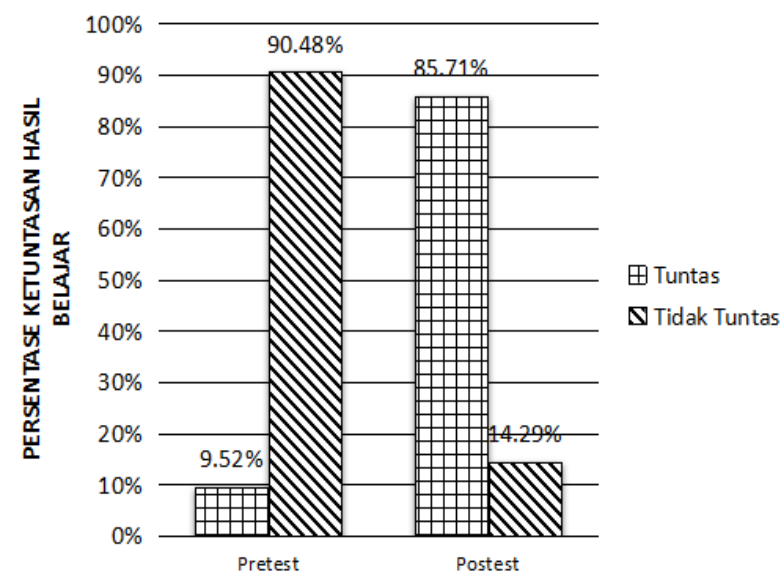

Gambar 1. Persentase Hasil Belajar Pretest dan Post test Siswa Pada Siklus I 
Dari grafik di atas dapat diketahui bahwa persentase ketuntasan hasil belajar siswa pada saat pembelajaran belum dimulai yaitu pretest, hasilnya tidak mencapai kriteria ketuntasan yaitu $\geq 85 \%$, hanya $9,52 \%$ siswa yang tuntas sedangkan siswa yang tidak tuntas $90,48 \%$. Hasil rata-rata nilai pretest pada siklus I adalah 42,62 . Sedangkan persentase ketuntasan hasil belajar siswa setelah pembelajaran telah diberikan yaitu post test, hasilnya sudah mencapai kriteria ketuntasan $\geq 85 \%$, yaitu $85,71 \%$ yang tuntas dan siswa tidak tuntas sebesar 14,29\%. Standar ketuntasan hasil belajar biologi siswa pada KKM SMA Negeri 3 Medan yaitu $\geq 70$. Dapat juga dilihat bahwa ada peningkatan dari nilai pretest ke nilai post test pada ketuntasan hasil belajar siswa. Hasil rata-rata nilai post test pada siklus I adalah 72,62.

Refleksi yang dilakukan untuk mengetahui sejauh mana keberhasilan dari model discovery learning yaitu menganalisis hasil belajar siswa, mengetahui kendala kendala pada siklus I, serta mencari solusi dari kendala-kendala yang dihadapi. Berdasarkan pengamatan siklus I ada beberapa kelemahan yang terjadi antara lain: (1) Kurangnya persiapan siswa mempelajari materi yang akan dipelajari, (2) Siswa kurang serius mendengarkan penjelasan oleh peneliti pada saat menyampaikan materi pembelajaran, (3) Beberapa siswa pada saat diminta untuk menyampaikan pendapat masih banyak yang malu mengeluarkan pendapatnya, (4) Pada saat mengerjakan soal post test masih ada siswa yang bertanya dan menyontek dengan temannya sehingga kelas tidak kondusif. Berdasarkan refleksi pada siklus I, maka dihasilkan langkah-langkah perbaikan sebagai usaha mengatasi kendala-kendala tersebut, agar tidak kembali muncul pada siklus II yaitu sebagai berikut: (1) Peneliti memotivasi siswa supaya mempelajari materi yang akan dipelajari pada pertemuan selanjutnya agar persiapan siswa dapat lebih baik, (2) Peneliti memotivasi siswa agar tertarik mengikuti pembelajaran sehingga siswa dapat lebih serius untuk mendengarkan penjelasan guru, (3) Memberi soal-soal latihan disela-sela kegiatan inti pembelajaran berlangsung sehingga siswa diharapkan siswa berani menyampaikan pendapatnya, (4) Peneliti dan observer harus lebih mengawasi pada saat pengerjaan soal post test berlangsung.

Siklus II dilaksanakan dengan model discovery learning menggunakan Media Interaktif dan dijabarkan hasil penelitiannya sebagai berikut: a. Perencanaan, hal-hal yang dilakukan pada tahap perencanaan siklus II adalah sebagai berikut: (1) Membuat RPP dengan kompetensi dasar "Menganalisis keterkaitan antara struktur sel pada jaringan hewan dengan fungsi organ pada hewan", (b) Menyiapkan sarana dan prasarana yang akan digunakan dalam proses pembelajaan berupa: Media interaktif, Infokus Proyektor dan LKS, (c) Menyusun dan menyiapkan jurnal penilaian sikap siswa, (d) Menyiapkan soal dan lembar jawaban evaluasi siswa. b. Pelaksanaan Tindakan, pada pertemuan ketiga siklus II dilaksanakan dengan cara Peneliti memulai pembelajaran dengan mengucapkan salam dan mengecek kehadiran siswa. Setelah mengkondisikan kesiapan belajar siswa maka guru memberikan soal pretest untuk mengetahui tingkat kemampuan siswa mengenai sub-materi organ dan sistem organ pada manusia sebelum diberikan perlakuan dengan melakukan model discovery learning. Setelah pretest selesai, guru memberikan apersepsi mengenai organ dan 
sistem organ pada manusia kemudian menyampaikan tujuan pembelajaran yang akan dicapai, yaitu: Siswa dapat mengidentifikasi dan menjelaskan tentang organ dan sistem organ pada manusia. Pada kegiatan inti pembelajaran, guru menjelaskan kepada siswa tentang jenis-jenis organ dan sistem organ pada manusia. Setelah itu peneliti siswa membentuk kelompok belajar yang sama seperti siklus I dan membagikan LKPD kepada siswa. Kemudian guru memberikan waktu kepada siswa untuk berdiskusi mengerjakan LKPD dengan mengacu pada media gambar yang telah disediakan. Setelah siswa selesai mengerjakan LKPD, maka guru meminta perwakilan setiap kelompok mempresentasikan hasil diskusinya dan kelompok yang lain menanggapi. Guru memberi koreksi apabila ada konsep yang salah dan meminta siswa untuk menggaris bawahi hal-hal yang penting pada buku atau mencatatnya di buku catatan. Guru mengakhiri pembelajaran dengan meminta perwakilan siswa untuk memberikan kesimpulan materi yang telah dipelajari. Guru mengakhiri pembelajaran dengan meminta perwakilan siswa untuk memberikan kesimpulan materi yanag telah dipelajari dan memberikan soal post test sebanyak 10 butir soal pilihan berganda, selesai itu guru menyuruh siswa agar mempelajari materi untuk pertemuan selanjutnya.

Selanjutnya untuk c. Observasi dan evaluasi pada siklus II diperoleh hasil-hasil sebagai berikut: Hasil Belajar Siswa diketahui dengan cara guru melaksanakan kegiatan evaluasi dengan memberikan pretest (10 soal pilihan berganda) dan post test (10 soal pilihan berganda) dan memberikan waktu 10 menit kepada siswa untuk mengerjakannya pada setiap sesi evaluasi. Berdasarkan nilai rata-rata yang diperoleh siswa, diketahui bahwa nilai rata-rata hasil belajar siswa adalah 86,91. Maka melalui persentase nilai dari masing-masing siswa dapat ditentukan tingkat penguasaan materi pelajaran dalam tes yang telah dilaksanakan. Pada pretest dan post test siklus II diperoleh persentase ketuntasan belajar siswa sebagaimana ditunjukkan pada gambar 2.

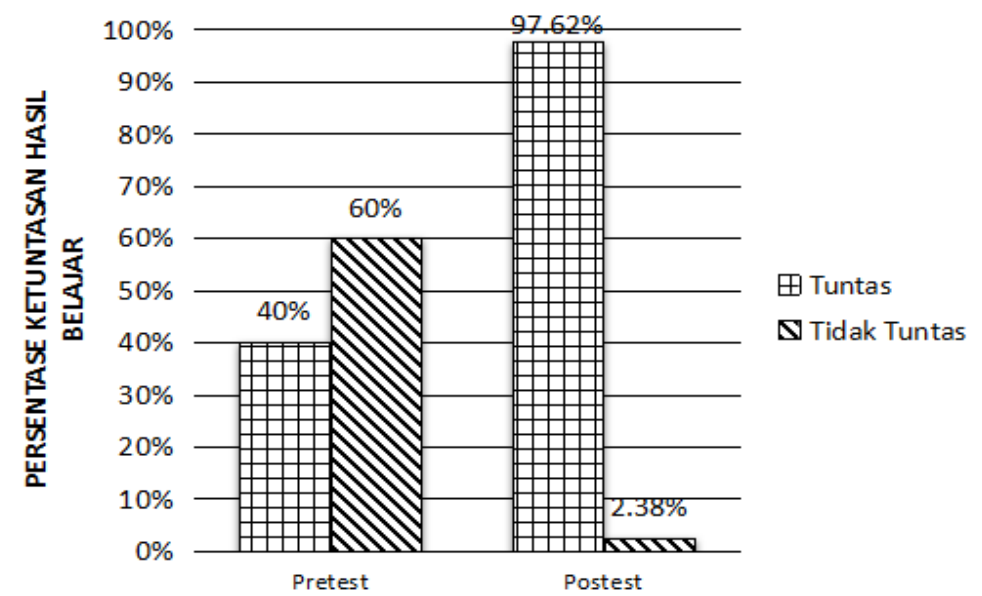

Gambar 2. Persentase Hasil Belajar Pretest dan Post test Siswa Pada Siklus II

Dari grafik di atas dapat diketahui bahwa persentase ketuntasan hasil belajar siswa pada saat pembelajaran belum dimulai yaitu pretest, hasilnya tidak mencapai kriteria ketuntasan yaitu $\geq 85 \%$, hanya $40 \%$ siswa yang tuntas sedangkan siswa yang tidak tuntas $60 \%$. Hasil rata-rata nilai pretest pada siklus I adalah 51,61. Setelah siswa 
diberikan pembelajaran dan dilakukan post test, hasilnya sudah mencapai kriteria ketuntasan $\geq 85 \%$, yaitu $97,62 \%$ yang tuntas dan siswa tidak tuntas hanya sebesar 2,38\%. Standar ketuntasan hasil belajar biologi siswa pada KKM SMA Negeri 3 Medan yaitu $\geq 70$. Dapat juga dilihat bahwa ada peningkatan pada nilai pretest dengan nilai post test pada ketuntasan hasil belajar siswa. Hasil rata-rata nilai post test pada siklus II adalah 86,91.

Hasil pengamatan hasil belajar pada siklus I dan siklus II dapat dilihat pada Tabel 1 berikut:

Tabel 1. Perbandingan Hasil Belajar Siswa pada Siklus I dan II

\begin{tabular}{ccccc}
\hline No. & Tes hasil belajar & Nilai rata-rata & $\begin{array}{c}\text { Jumlah siswa } \\
\text { yang tuntas }\end{array}$ & $\begin{array}{c}\text { Persentase } \\
\text { ketuntasan }\end{array}$ \\
\hline 1 & Siklus I & 71,8 & 36 & $85,71 \%$ \\
\hline 2 & Siklus II & 86,91 & 41 & $97,62 \%$ \\
\hline
\end{tabular}

Berdasarkan hasil pengamatan pada siklus I, pada post test I persentase ketuntasan mencapai $85,71 \%$. Target dalam penelitian ini adalah siswa mampu mencapai ketuntasan sampai $90 \%$ bahkan lebih. Ternyata hasil yang diperoleh pada siklus I belum mencapai target, sehingga peneliti melanjutkan penelitian ke siklus II untuk mencapai ketuntasan minimal dalam penelitian ini.

Dari tabel di atas dapat dilihat bahwa hasil belajar dari siklus I dan siklus II mengalami peningkatan dan ketuntasan juga mengalami peningkatan. Pada post test I sudah mencapai ketuntasan yaitu sebesar $85,71 \%$ sedangkan pada post test II telah mencapai ketuntasan dan lebih tinggi dari post test I yaitu sebesar 97,62\%. Terjadi peningkatan dari siklus I dan II yaitu sebesar $11,91 \%$. Dapat dikatakan bahwa pada siklus II peneliti telah berhasil melakukan perbaikan pembelajaran dari pelaksanaan siklus I.

Berdasarkan data-data yang telah dipaparkan di atas, maka perbaikan pembelajaran biologi yang telah dilaksanakan di kelas XI MIA-8 SMA Negeri 3 Medan dengan menerapkan model discovery learning ternyata dapat meningkatkan hasil belajar siswa. Pada siklus II perbaikan kegiatan pembelajaran yang dilakukan yaitu memberi media gambar mengenai organ dan sistem organ manusia pada saat kegiatan inti berlangsung, hal ini bertujuan agar siswa dapat memahami dan mengaplikasikan pengetahuan yang baru didapat. Dengan cara tersebut siswa dapat lebih mudah dalam mengikuti pelajaran dan membantu guru mengetahui kemampuan kognitif siswanya.

Adanya peningkatan hasil belajar siswa pada tiap siklus tersebut membuktikan bahwa penerapan model pembelajaran discovery learning menggunakan media interaktif dan LKPD melalui alur PTK menunjukkan peningkatan hasil belajar biologi pada siklus berikutnya lebih baik dibandingkan dengan siklus sebelumnya. Dengan mengacu pada hasil tersebut dapat dinyatakan bahwa tingkat penguasaan siswa pada setiap siklus meningkat secara signifikan. Hasil penelitian ini didukung oleh peneliti terdahulu, yaitu penelitian dari Rosarina, G. (2016) yang menerapkan model pembelajaran discovery learning, berdasarkan hasil temuan dan pembahasan, dapat direkomendasikan bahwa dengan menerapkan model discovery learning merupakan suatu alternatif untuk meningkatkan hasil belajar siswa. Peningkatan ini dilihat dari 
persentase ketuntasan tiap siklus. Siswa yang dinyatakan tuntas pada siklus I berdasarkan hasil tes ada 7 siswa (26,92\%), siklus II menjadi 17 siswa $(65,38 \%)$ dan siklus III 23 siswa (88,46\%). Peningkatan hasil belajar dengan implementasi discovery learning adalah hasil penelitian Muhamad,N. (2016) menyebutkan bahwa model pembelajaran discovery learning meningkatkan hasil belajar siswa karena kepercayaan diri siswa yang meningkat. Nilai rata-rata pretes 30,76 , pada siklus I meningkat menjadi 67,50, dan pada siklus II mengalami kenaikan dengan nilai 79,50, pada siklus III mengalami peningkatan pula dengan nilai 86,33.

Secara keseluruhan hasil penelitian tindakan kelas yang telah dipaparkan menunjukkan bahwa kegiatan pembelajaran dengan menerapkan model pembelajaran Discovery learning dapat meningkatkan hasil belajar siswa sama halnya dengan penelitian implementasi Discovery learning pada pembelajaran biologi yang dilakukan di kelas XI MIA-8 SMA Negeri 3 Medan.

\section{SIMPULAN DAN SARAN}

Implementasi discovery learning dapat meningkatkan hasil belajar siswa dalam pembelajaran biologi Materi Struktur dan Fungsi Jaringan Hewan di kelas XI MIA-8 SMA Negeri 3 Medan.

Saran dari penelitian ini yang dapat dilakukan adalah adanya penelitian tindak lanjut mengenai implementasi discovery learning dikombinasikan dengan model/metode pembelajaran yang lain serta penerapan teknologi agar proses pembelajaran lebih variatif dan inovatif.

\section{UCAPAN TERIMA KASIH}

Jurnal ini ditulis berdasarkan hasil Penelitan Tindakan Kelas (PTK) program Pendidikan Profesi Guru (PPG). Saya berterima kasih banyak kepada lbu Dr. Fauziyah Harahap, M.Si. sebagai Dosen Pembimbing PTK saya, dan Ibu Dessy C. Sianturi, S.Pd., M.Si. selaku guru pamong saya selama mengikuti PPG.

\section{RUJUKAN}

Arikunto, S. (2010). Prosedur Penelitian Suatu pendekatan praktik. Jakarta: PT. Rineka Cipta

Azhari, (2015). Penerapan model pembelajaran discovery learning terhadap peningkatan hasil belajar siswa kelas XI-IPA1 pada materi sistem pernapasan di SMA Negeri Unggul Sigli, Jurnal Biologi Edukasi Edisi 14, Volume 7 Nomor 1 , hal 13-21

Campbell, et al. (2008). Biologi Jilid 1Edisi 8. Jakarta: Erlangga

Daryanto. (2007). Evaluasi Pendidikan, Jakarta: PT. Rineka Cipta

Dimyati dan Mudjiono. (2002). Belajar Dan Pembelajaran. Jakarta: PT Rineka Cipta

Muhamad,N. (2016). Pengaruh Model Discovery learning untuk Meningkatkan Representasi Matematis dan Percaya Diri Siswa. Jurnal Pendidikan Universitas Garut Fakultas Pendidikan Islam dan Keguruan Universitas Garut ISSN: 1907 932X

Nasution, L.,M. (2017). Statistik Deskriptif. Jurnal Hikmah, Volume 14, No. 1 Oemar,Hamalik. (2006). Proses Belajar Mengajar. Bandung: Bumi Aksara 
Pangaribowo, D., Keliat, N., Sastrodihardjo,S., Hutangoal.,D., (2017). Penerapan model Pembelajaran Discovery Learning dan Permainan Smart Case untuk Meningkatkan Hasil Belajar Siswa Kelas VII C SMP Kristen 2 Salatiga. BIOEDUKASI Volume 10, Nomor 1 Halaman 47- 57

Putrayasa, I., Syahruddin, H. \& Margunayasa, I. (2014). Pengaruh Model Pembelajaran Discovery Learning Dan Minat Belajar Terhadap Hasil Belajar Ipa Siswa, II(1), hlm 1-11.

Rosarina, G., Sudin, A., Sujana, A., (2016). Penerapan Model Discovery Learning Untuk Meningkatkan Hasil Belajar Siswa Pada Materi Perubahan Wujud Benda, Jurnal Pena IImiah Vol.1, No.1, hlm 371-380

Sani, R. (2013). Inovasi Pembelajaran. Jakarta: Bumi Aksara

Sudjana, Nana. (2009). Penilaian Hasil Proses Belajar Mengajar. Bandung: PT. Remaja Rosdakarya.

Sujana, A. (2014). Pendidikan IPA, Bandung: Rizqi Press.

Trihartanti, W. (2015). Penerapan pendekatan saintifik pada materi dunia tumbuhan di SMA negeri 1 Gedangan sidoarjo. BioEdu Berkala IImiah Pendidikan Biologi, Vol.4 No.1 ISSN: 2302-9528

Widiadnyana I W., Sadia I W., Suastra I W. (2014). Penelitian yang berjudul Pengaruh Model Discovery Learning Terhadap Pemahaman Konsep IPA dan Sikap IImiah Siswa SMP. e-Journal Program Pascasarjana Universitas Pendidikan Ganesha Program Studi IPA, Volume 4.

Yuliana, N. (2018). Penggunaan Model Pembelajaran Discovery Learning Dalam Peningkatan Hasil Belajar Siswa di Sekolah Dasar. Jurnal Ilmiah Pendidikan dan Pembelajaran. PPs Universitas Pendidikan Ganesha 